\title{
Does the SEC's Waiver of IFRS to U.S. GAAP Reconciliation Improve the Quality of Financial Reporting?
}

\author{
Chia-Ling Chao ${ }^{1} \&$ Shwu-Min Horng ${ }^{2}$ \\ ${ }^{1}$ Department of Accounting and Information Technology, National Chung Cheng University, Taiwan \\ 2 Department of Business Administration, National Chengchi University, Taiwan
}

Correspondence: Shwu-Min Horng, Department of Business Administration, National Chengchi University, No. 64, Sec. 2, ZhiNan Rd., Wenshan District, Taipei City 11605, Taiwan, Tel: 886-2-2939-3091 ext. 81033, E-mail: shorng@nccu.edu.tw

Received: April 20, 2013

Accepted: June 30, 2013

Online Published: July 8, 2013

doi:10.5430/afr.v2n3p78

URL: http://dx.doi.org/10.5430/afr.v2n3p78

\begin{abstract}
This paper compares accounting-quality metrics for foreign firms before and after the SEC waived the reconciliation requirement for IFRS firms. We find that foreign issuers applying IFRS exhibit more income smoothing and less timely recognition of losses than do foreign firms filing U.S. GAAP reconciliations in the IFRS reporting period. However, we also find that accounting amounts are more value relevant for IFRS firms than their counterparts. Differences in accounting quality between the two sets of firms in the U.S. GAAP reconciliation period do not account for the IFRS reporting-period differences. Our findings also document that foreign firms filing U.S. GAAP reconciliations experience a greater improvement in accounting quality in terms of less earnings smoothing and more timely recognition of losses than do foreign issuers adopting IFRS between the U.S. GAAP reconciliation and IFRS reporting periods. Overall, the combined evidence suggests that application of IFRS by non-U.S. firms has not enhanced financial reporting comparability with firms filing U.S. GAAP reconciliations. The above implications are robust to a number of alternative specifications.
\end{abstract}

Keywords: Accounting quality, Earnings management, Timely loss recognition, Value relevance

\section{Introduction}

In December 2007, the U.S. Securities and Exchange Commission (SEC) adopted Securities Act Release No. 8879, "Acceptance from Foreign Private Issuers of Financial Statements Prepared in Accordance with IFRS without Reconciliation to U.S. GAAP." The SEC's new rule applies to financial statements issued for fiscal years ending after November 15, 2007, and interim periods after the effective date. The ruling has significant implications for U.S. firms, U.S. capital markets, and accounting practitioners and researchers.

Prior to 2008, the SEC required foreign registrants to file a Form 20-F, analogous to a Form 10-K, within six months after the fiscal year-end. In a Form 20-F, foreign private issuers reconciled their earnings and stockholders' equity measures to U.S. GAAP. The SEC's main motivation for the requirement was to protect U.S. investors who may not be familiar with non-U.S. accounting practices (Siconolfi and Salwen, 1992). However, the reconciliation requirement also suggests that U.S. GAAP is not only superior to foreign accounting standards, but is also superior to standards issued by the International Accounting Standards Board (IASB). (Note 1)

In contrast, the new ruling indicates the SEC's confidence that IFRS represents a single set of high-quality accounting standards and that financial reports prepared under IFRS are as informative and useful as those prepared under U.S. GAAP. However, it is noteworthy that the Financial Accounting Standards Committee (FASC) and the Financial Reporting Policy Committee (FRPC), both part of the American Accounting Association (AAA), reached dissimilar conclusions in recent studies of the value of $20-\mathrm{F}$ reconciliations to investors. The FASC argues that "allowing foreign companies to use IFRS without costly reconciliations to U.S. GAAP is likely to make U.S. stock exchanges more competitive..." (AAA, 2008a), whereas the FRPC indicates that "the research on the U.S. GAAP-IFRS reconciliation suggests that material differences between IFRS and U.S. GAAP exist and that 
information contained in the reconciliations is reflected in investment decisions made by U.S. investors" (AAA, 2008b). The FRPC concludes, after reviewing the academic literature, that it "does not support the SEC's decision to eliminate the U.S. GAAP-IFRS reconciliation requirement for foreign-private issuers" (AAA, 2008b).

Users of foreign firms' financial statements also disagree among themselves on the SEC's decision to allow IFRS filers to remove the reconciliation to U.S. GAAP. The CFA Institute, which represents investment analysts and portfolio managers, states in its comment letter to the SEC that "to the extent accounting standards have not yet converged (or new differences develop), investment professionals rely on the reconciliation as an efficient and cost-effective way of bringing to their attention the material differences in accounting" (CFA Institute, 2007). The CFA Institute further argues that "we believe that it is premature to eliminate this requirement at this time" (CFA Institute, 2007). In contrast, Fitch Ratings, the third largest rating agency, argues that it "does not pay very much attention to US GAAP reconciliations in 20-F reports and does not consider that their elimination would have a substantial impact on [its] ability to conduct analysis" (Fitch Ratings, 2007).

This policy debate on whether IFRS reporting is comparable to U.S. GAAP is what motivates this study. The controversy is complex because the features of any financial reporting system affect the application of any set of accounting standards (Barth, Landsman, \& Lang, 2008). Although the SEC ruling is intended as a step toward convergence of U.S. GAAP and IFRS, the decision to waive the U.S. GAAP reconciliation requirement and allow IFRS is controversial. Against this background and concern, this paper examines properties of accounting information for cross-listed foreign firms on the U.S. stock exchanges across two periods: the U.S. GAAP reconciliation period and the IFRS reporting period.

Our investigation starts by comparing accounting-quality metrics for foreign issuers that apply IFRS to those for a matched sample of foreign firms that do not in the IFRS reporting periods. The results indicate that foreign issuers applying IFRS demonstrate more earnings management and less timely recognition of losses than do foreign firms filing U.S. GAAP reconciliations in the IFRS reporting period. However, the results also show that IFRS firms exhibit a higher association of accounting amounts with share prices and returns. Differences in accounting quality between the two sets of firms in the U.S. GAAP reconciliation period do not account for the IFRS reporting-period differences. We also compare accounting-quality metrics for IFRS firms in the periods before and after the SEC waiver and examine whether the change in accounting quality for IFRS firms between the U.S. GAAP reconciliation and IFRS reporting periods is different from that for their counterparts. The results document that foreign firms filing U.S. GAAP reconciliations experience a greater improvement in accounting quality in terms of less earnings smoothing and more timely recognition of losses than do foreign issuers adopting IFRS between the U.S. GAAP reconciliation and IFRS reporting periods. Overall, the combined evidence suggests that for non-U.S. firms, applying IFRS does not enhance financial reporting comparability with firms filing U.S. GAAP reconciliations.

This study contributes to the accounting literature in the following ways. First, to the best of our knowledge, this paper provides one of the first empirical evidence of U.S. GAAP and IFRS comparability after the SEC waived the reconciliation requirement for foreign issuers registered in the United States. Second, this paper also contributes to the debate over whether the SEC should allow foreign firms to list their securities in the U.S. market without U.S. GAAP reconciliation if they follow IFRS. Third, given that extant research provides inconclusive evidence of whether U.S. GAAP or IFRS produces higher-quality accounting despite the convergence efforts made jointly by the Financial Accounting Standards Board (FASB) and IASB, this study contributes to the current policy debates about the possible adoption of IFRS by U.S. firms in the future.

The remainder of this paper is organized as follows. Section 2 discusses prior research. Sections 3 and 4 develop the research questions and explain the research design. Section 5 reviews the sample selection and industry breakdowns. Section 6 presents the empirical results. Section 7 discusses several sensitivity tests. Section 8 concludes and offers directions for future research.

\section{Literature Review}

\subsection{Accounting Quality}

Many studies examine properties of accounting information across different accounting regimes. The findings are generally mixed. For instance, Ball, Robin, and Wu (2003) compare the timeliness of loss recognition across several countries that have accounting systems based on common law sources. They find significant variation in earnings across these countries and conclude that international differences in reporting incentives inherently limit the extent to which homogenization of accounting standards can achieve accounting comparability. Leuz, Nanda, and Wysocki 
(2003) also report large international differences across several earnings-management measures, including loss avoidance and income smoothing.

Furthermore, Lang, Raedy, and Yetman (2003) provide evidence that foreign firms cross-listing on U.S. exchanges appear to be less aggressive in their earnings management and tend to report accounting information that is more conservative, takes more timely account of bad news, and is more strongly associated with share price. They attribute the results to differences in accounting quality before listing. Ball and Shivakumar (2005) also investigate timely loss recognition in a large sample of U.K. private and public firms. They find that timely loss recognition is substantially less prevalent in private firms than in public firms, regardless of equivalent regulatory rules. Lang, Raedy, and Wilson (2006) also document that for non-U.S. firms, reconciled earnings are not comparable to those reported by U.S. firms. Bradshaw and Miller (2008) examine a sample of non-U.S. firms that adopt U.S. GAAP and find that properties of their accounting results still do not fully compare to U.S. firms, although those properties changed significantly after the adoption. Moreover, Barth et al. (2008) find that firms adopting International Accounting Standards (IAS), the predecessor of IFRS, from 21 countries generally exhibit less earnings management, more timely loss recognition, and more value relevance of accounting amounts relative to firms applying non-U.S. domestic GAAP.

In contrast, Van, Tendeloo, and Vanstraelen (2005) document that German firms applying IAS do not exhibit significant differences in earnings management compared to those adopting German standards. Likewise, Hung and Subramanyam (2007) find weak evidence that firms adopting IAS recognize economic losses in a timelier manner than firms applying German GAAP, suggesting that conditional conservatism in reporting IAS income may not be higher than that of its counterpart. One possible explanation for the mixed findings in this line of research is that the studies differ in effectively controlling for economic environment and incentives associated with applying a particular set of accounting standards.

\subsection{U.S. GAAP and IFRS Comparisons}

Prior studies comparing U.S. GAAP and IAS/IFRS mainly focus on the effects of using two different accounting standards on the capital markets. Harris and Muller (1999) examine a sample of non-U.S. firms that report reconciliations from IAS to U.S. GAAP, for example, and document that U.S. GAAP earnings-reconciliation amounts are more highly associated with stock returns than IAS measures are, suggesting that U.S. investors prefer financial statements prepared under U.S. GAAP. Chen and Sami (2008) investigate cross-listed IAS filers and find a positive association between the abnormal trading volume and the earnings reconciliation adjustment in the two-day window surrounding the release of the reconciliation. Their results suggest that investors rely on reconciliation information to make valuation decisions. Using a sample of IFRS firms in 27 countries that adopted IFRS and a sample of U.S. firms matched on size and industry, Barth, Landsman, Lang, and Williams, (2012) document that both before and after IFRS firms adopt IFRS, accounting quality is higher for U.S. firms.

On the other hand, Bartov, Goldberg, and Kim (2005) find a stronger relationship between earnings and returns for IAS and U.S. GAAP over German GAAP, but they are unable to document any significant difference in the earnings/returns association between IAS and U.S. GAAP. (Note 2) The authors conclude that U.S. GAAP is not superior to IAS in terms of value relevance. Leuz (2003) uses a sample of German firms to examine information asymmetry and market liquidity associated with IAS and U.S. GAAP and finds that differences in the bid-ask spread, share turnover, analyst forecast dispersion, and initial public offering underpricing between U.S. GAAP and IAS firms are statistically insignificant and economically small. Leuz's findings suggest that U.S. GAAP does not produce higher-quality information than IAS. Thus, the evidence is inconclusive regarding whether U.S. GAAP and IFRS are comparable.

\subsection{SEC's Waiver of IFRS to U.S. GAAP Reconciliation}

Extant research on U.S. GAAP reconciliation provides inconclusive evidence that permitting the choice of IFRS reporting in the U.S. induces significant capital market effects. Jiang, Petroni, and Wang, (2010) find no association between the reconciliation adjustments and abnormal trading volume, abnormal return volatility, and changes in the bid-ask spread around the release of the reconciliation. In addition, they document no evidence that eliminating the reconciliation changed the investors' perception of the 20-Fs in 2008 relative to 2007. However, the authors do find that the removal of the reconciliation requirement could have the beneficial effect of significantly accelerating financial reporting. Kim, $\mathrm{Li}$, and $\mathrm{Li} \mathrm{(2012)}$ provide no evidence that IFRS-reporting firms experience a greater change in market liquidity and the probability of informed trading in the year after the elimination, relative to firms that do not adopt IFRS. Their results also find no support for the notion that the elimination has a significant impact on cost of equity, analysts' forecast error, bias and dispersion, institutional ownership, and stock price efficiency and 
synchronicity, implying that there is no informational loss or greater information asymmetry as a result of the rule change.

Kim et al. (2012)'s findings, however, are inconsistent with Han and He (2013) that document significant increases in foreign firms' cost of equity in the period that the SEC permits the use of IFRS reporting. In addition, Hansen, Pownall, Prakash, and Vulcheva (2012) find that IFRS filers with stronger incentives to provide informative disclosures experienced significant increases in the information content of their earnings after the elimination of the reconciliation requirement. They document no decrease in the information content of earnings for firms without such reporting incentives.

In sum, the aforementioned studies provide inconclusive evidence on the usefulness of reconciliation information and the comparability of U.S. GAAP and IFRS. Accordingly, more evidence is needed, and the elimination of the reconciliation requirement provides a unique setting that allows us to provide new insight on whether this rule change affects properties of accounting information for firms cross-listing on the U.S. exchanges across two periods: the U.S. GAAP reconciliation period and the IFRS reporting period.

\section{Research Questions}

The opposing views from FRPC, which is the academic arm of the U.S. accounting profession, and from users of foreign firms' financial reports (e.g., the CFA Institute) regarding the SEC's decision to remove the reconciliation requirement are not surprising, given that the aforementioned literature does not settle the question of whether IFRS is as good as U.S. GAAP. To the extent that U.S. GAAP and IFRS are comparable in terms of quality, there should be no significant difference in accounting properties when non-U.S. firms switch from U.S. GAAP to IFRS. This leads to the following research questions (RQs):

RQ1: Does accounting quality for foreign issuers applying IFRS differ from that for foreign firms filing U.S. GAAP reconciliations after the elimination of the reconciliation requirement?

In addition to examining the differences between foreign issuers that apply IFRS and U.S. GAAP in the IFRS reporting period, this paper also considers two potential causes for these differences: pre-existing differences and changes between the U.S. GAAP reconciliation and IFRS reporting periods. If self-selection drives the differences, those differences should be evident in the reconciliation period. If the differences reflect changes around the SEC's waiver of the reconciliation requirement, they should be apparent in a comparison of IFRS adopters before and after the removal of the requirement. Specifically, if IFRS results in better presentation of foreign issuers' financial condition, accounting quality for IFRS adopters should improve after they are free of the U.S. GAAP reconciliation requirement. This leads to the following RQs:

RQ2: Does accounting quality for foreign issuers applying IFRS differ from that for foreign firms filing U.S. GAAP reconciliations before the elimination of the reconciliation requirement?

RQ3: Does accounting quality for foreign issuers applying IFRS before and after the elimination of the reconciliation requirement differ?

One caveat of comparing accounting attributes of IFRS firms between the two periods is that it could also detect improvement or deterioration in accounting quality due to changes in economic environment that are unattributable to the financial reporting system. Accordingly, this paper also examines whether the change in accounting quality for IFRS filers between the two regimes is greater than that for U.S. GAAP adopters. This leads to the following RQ:

RQ4: Does the change in accounting quality for foreign issuers applying IFRS between the U.S. GAAP reconciliation and IFRS reporting periods differ from that for foreign firms filing U.S. GAAP reconciliations?

Figure 1 shows the samples/regimes that our RQs aim to examine in this study. The vertical axis represents the accounting standards (i.e., IFRS and U.S. GAAP) applied by foreign firms cross-listing on U.S. exchanges. The horizontal axis represents the accounting regimes (i.e., U.S. GAAP reconciliation period and IFRS reporting periods, as denoted by PRE and POST, respectively). Specifically, Quadrant 2 (4) represents foreign firms that adopt IFRS (file U.S. GAAP reconciliations) after the elimination of the reconciliation requirement. Quadrant 1 (3) represents IFRS filers (firms applying U.S. GAAP reconciliations) before the SEC waived the U.S. GAAP reconciliation requirement. In sum, RQ1 aims to compare Quadrants 2 and 4. RQ2 compares Quadrants 1 and 3. RQ3 compares Quadrants 1 and 2. RQ4 examines the differences between Quadrants 1 and 2 relative to that between Quadrants 3 and 4. 


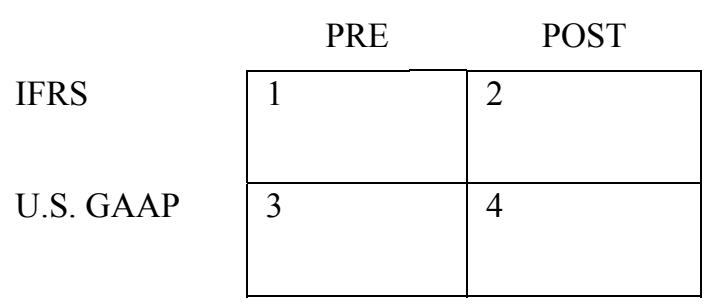

Figure 1. Groupings of the sample based on accounting standards and periods

\section{Research Design}

Following prior research (e.g., Ball \& Shivakumar, 2005, 2006; Barth et al., 2008; Lang et al., 2006; Lang et al., 2003; Leuz et al., 2003), this paper predicts that firms with higher accounting quality demonstrate less earnings management, more timely loss recognition, and more value relevance of accounting amounts. Accordingly, this paper focuses on three accounting properties: (1) earnings management, (2) conservatism/timeliness, and (3) value relevance.

The first category is based on accruals, which serve as the defining attribute of any accounting system and represent adjustments made to cash flows to arrive at reported income. Accordingly, discrepancies in accounting-method choices should affect the magnitude of accruals for a specified level of cash flows. The second category captures conservatism/timeliness of loss recognition. Timeliness in recognizing bad news is a unique attribute across different reporting environments. With respect to value relevance, the stock prices of firms with higher-quality accounting should be more associated with earnings and equity book values because their financial statements better reflect underlying economics. We devote the remainder of this section to describing the measurement of these three accounting properties.

\subsection{Earnings Management}

Firms with less income smoothing exhibit more earnings variability. Accordingly, our first earnings-management metric is based on the variability of the change in net income deflated by total assets, $\Delta N I_{i t}$. However, a change in net income is likely to reflect various factors unrelated to the financial reporting system, such as economic environment and reporting incentives. Thus, the income-variability metric is the variance of the residuals from the regression of change in net income on variables identified in prior research as controls for these factors:

$$
\begin{aligned}
\Delta N I_{i t}=\alpha_{0}+\alpha_{1} S I Z E_{i t}+\alpha_{2} \text { GROWTH }_{i t} & +\alpha_{3} C S_{i t}+\alpha_{4} L E V_{i t}+\alpha_{5} T L_{i t}+\alpha_{6} S A L E S_{i t}+\alpha_{7} O C F_{i t}+\alpha_{8} A U D_{i t} \\
& +\alpha_{9} N U M E X_{i t}+\varepsilon_{i t}
\end{aligned}
$$

where $\Delta N I$ is the change in net income, where net income is divided by total assets. SIZE is firm size, which equals the natural logarithm of end-of-year market value of equity. GROWTH is the percentage change in sales. CS is the percentage change in common stock. $L E V$ is leverage, which equals total liabilities divided by total assets. $T L$ is the percentage change in total liabilities. SALES is sales, scaled by total assets. $O C F$ is net cash flow from operating activities, scaled by total assets. $A U D$ is an indicator variable equal to 1 if the firm's auditor is among the big-four accounting firms, and 0 otherwise. NUMEX is the number of exchanges on which a firm's stock is listed.

We estimate equation (1) by pooling observations that are relevant to the particular comparison tested. For instance, when comparing foreign issuers adopting U.S. GAAP and IFRS in the IFRS reporting period, we pool all sample years in the period. For this comparison, the variability of $\Delta N I_{i t}^{*}$ is the variance of the U.S. GAAP and IFRS adopters' respective residuals from equation (1) in the IFRS reporting period. When comparing IFRS filers in the U.S. GAAP reconciliation and IFRS reporting periods, we pool all sample years for foreign issuers applying IFRS. For this comparison, the variability of $\Delta N I_{i t}^{*}$ is the respective variance of residuals for IFRS adopters in the two periods. The difference in the variability of $\Delta N I_{i t}^{*}$ between the U.S. GAAP reconciliation and IFRS reporting periods for U.S. GAAP and IFRS filers is the difference between the resulting metrics for these firms. A smaller variance is evidence of income smoothing.

Our second earnings-management metric relies on the mean ratio of the variability of the change in net income, $\Delta N I_{i t}$, to the variability of the change in operating cash flows, $\triangle O C F_{i t}$. Differences in accounting methods should not influence cash flows, but they should affect the magnitude of accruals for a given level of cash flows. To the extent 
that firms use accruals as an earnings-management instrument, the variability of the change in net income should be lower than that of operating cash flows. Accordingly, our cash flows variability metric, the variability of $\triangle O C F_{i t}^{*}$, is the variance of the residuals from the regression of change in operating cash flows on variables similar to those in equation (1):

$$
\begin{aligned}
\triangle O C F_{i t}=\beta_{0}+\beta_{1} S_{S I E}+E_{i t}+\beta_{2} G R O W T H_{i t}+ & \beta_{3} C S_{i t}+\beta_{4} L E V_{i t}+\beta_{5} T L_{i t}+\beta_{6} S A L E S_{i t}+\beta_{7} O C F_{i t}+\beta_{8} A U D_{i t} \\
& +\beta_{9} N U M E X_{i t}+\varepsilon_{i t}
\end{aligned}
$$

As with equation (1), this paper pools observations appropriate for the particular comparison. The resulting second measure of earnings smoothing is the ratio of the variability of $\Delta N I_{i t}^{*}$ to variability of $\triangle O C F_{i t}^{*}$. A smaller ratio indicates income smoothing.

Our third-earnings management metric compares correlations of residuals from equations (3) and (4), $A C_{i t}^{*}$ and $O C F_{i t}^{*} . O C F_{i t}$ is net cash flows from operations, and $A C_{i t}$ is the difference between net income and net cash flows from operations. Both variables are scaled by end-of-year total assets. As with equations (1) and (2), $A C_{i t}$ and $O C F_{i t}$ are regressed on the similar control variables, but excluding $O C F_{i t}$ :

$$
\begin{aligned}
A C_{i t}=\delta_{0}+\delta_{1} S_{I Z E_{i t}}+\delta_{2} \text { GROWTH }_{i t}+\delta_{3} C S_{i t} & +\delta_{4} L E V_{i t}+\delta_{5} T L_{i t}+\delta_{6} S_{A L E S_{i t}}+\delta_{7} A U D_{i t}+\delta_{8} N U M E X_{i t} \\
& +\varepsilon_{i t} \\
O C F_{i t}=\eta_{0}+\eta_{1} S_{I Z E_{i t}}+\eta_{2} G R O W T H_{i t}+\eta_{3} C S_{i t} & +\eta_{4} L E V_{i t}+\eta_{5} T L_{i t}+\eta_{6} S A L E S_{i t}+\eta_{7} A U D_{i t}+\eta_{8} N U M E X_{i t} \\
& +\varepsilon_{i t}
\end{aligned}
$$

We also pool observations appropriately for the comparison. Negative correlation between $A C^{*}$ and $O C F^{*}$ is evidence of income smoothing because managers respond to negative cash flows by increasing accruals.

Prior research (e.g., Leuz et al., 2003) indicates that positive income is a common goal of earnings management. The underlying notion is that managers prefer to report small positive net income rather than negative net income. Accordingly, this paper also examines whether foreign firms applying IFRS manage earnings upward more frequently than those following U.S. GAAP in the reconciliation (IFRS) period. Specifically, our metric for managing toward positive earnings is the coefficient on small positive net income, $P O S_{i t}$, in the regressions given by equations (5) and (6). When comparing foreign issuers applying IFRS and U.S. GAAP in the IFRS (reconciliation) period, we estimate equation (5) by pooling observations from the IFRS (reconciliation) period.

$$
\begin{gathered}
I F R S_{i t}=\theta_{0}+\theta_{1} \text { POS }_{i t}+\theta_{2} \text { SIZE }_{i t}+ \\
\theta_{3} \text { GROWTH }_{i t}+\theta_{4} C S_{i t}+\theta_{5} L E V_{i t}+\theta_{6} T L_{i t}+\theta_{7} \text { SALES }_{i t}+\theta_{8} O C F_{i t} \\
+\theta_{9} A U D_{i t}+\theta_{10} N U M E X_{i t}+\varepsilon_{i t}
\end{gathered}
$$

where $I F R S_{i t}$ is an indicator variable equal to 1 for foreign issuers adopting IFRS and 0 for those complying with U.S. GAAP reconciliations. $P O S_{i t}$ is an indicator variable equal to 1 if net income deflated by total assets is between 0 and 0.01 ; it equals 0 otherwise. A significantly positive coefficient on $P O S_{i t}$ indicates that IFRS filers manage earnings toward small positive amounts more frequently than do U.S. GAAP filers. When comparing IFRS adopters in the U.S. GAAP reconciliation and IFRS reporting periods, this paper estimates equation (6) by pooling IFRS firm observations from all sample years.

$$
\begin{gathered}
\operatorname{POST}_{i t}=\varphi_{0}+\varphi_{1} \text { POS }_{i t}+\varphi_{2} \text { SIZE }_{i t}+\varphi_{3} \text { GROWTH }_{i t}+\varphi_{4} C S_{i t}+\varphi_{5} L E V_{i t}+\varphi_{6} T L_{i t}+\varphi_{7} S_{S A L E S_{i t}}+\varphi_{8} O C F_{i t} \\
+\varphi_{9} A U D_{i t}+\varphi_{10} N U M E X_{i t}+\varepsilon_{i t}
\end{gathered}
$$

where $P O S T_{i t}$ is an indicator variable equal to 1 for observations in the IFRS reporting period and 0 for those in the U.S. GAAP reconciliation period. A significantly positive coefficient on $P O S_{i t}$ indicates that IFRS filers manage earnings toward small positive amounts more frequently in the IFRS reporting period than in the U.S. GAAP reconciliation period.

\subsection{Conservatism/Timeliness of Loss Recognition}

One feature of high-quality earnings is that companies recognize large losses as they occur rather than deferring them to future periods. The underlying notion is that if earnings are smoothed, large losses should be less frequent. Accordingly, our first metric for timely loss recognition is the coefficient on large negative net income, $N E G_{i t}$, in the regressions given by equations (7) and (8) (Ball, Robin, \& Wu, 2003; Ball \& Shivakumar, 2005; Barth et al., 2008; Lang et al., 2003; Lang et al., 2006). When comparing foreign firms applying IFRS and U.S. GAAP in the reconciliation (IFRS) period, we estimate equation (7) by pooling observations from the reconciliation (IFRS) period. 


$$
\begin{gathered}
\operatorname{IFRS}_{i t}=\mu_{0}+\mu_{1} N E G_{i t}+\mu_{2} \operatorname{SIZE}_{i t}+\mu_{3} \text { GROWTH }_{i t}+\mu_{4} C S_{i t}+\mu_{5} L E V_{i t}+\mu_{6} T L_{i t}+\mu_{7} S_{A L E S_{i t}}+\mu_{8} O C F_{i t} \\
+\mu_{9} A U D_{i t}+\mu_{10} N U M E X_{i t}+\varepsilon_{i t}
\end{gathered}
$$

where $N E G_{i t}$ is an indicator variable equal to 1 if net income scaled by total assets is less than -0.20 ; it equals 0 otherwise. A significantly positive coefficient on $N E G_{i t}$ indicates that IFRS filers recognize large losses more frequently than do U.S. GAAP filers. As with equation (5), this paper draws inferences on the coefficient on $N E G_{i t}$ from equation (7) rather than directly comparing the frequencies of large losses.

When comparing IFRS adopters in the U.S. GAAP reconciliation and IFRS reporting periods, we estimate equation (8) by pooling IFRS firm observations from all sample years.

$$
\begin{gathered}
P O S T_{i t}=\zeta_{0}+\zeta_{1} N E G_{i t}+\zeta_{2} S I Z E_{i t}+\zeta_{3} G R O W T H_{i t}+\zeta_{4} C S_{i t}+\zeta_{5} L E V_{i t}+\zeta_{6} T L_{i t}+\zeta_{7} S A L E S_{i t}+\zeta_{8} O C F_{i t} \\
+\zeta_{9} A U D_{i t}+\zeta_{10} N U M E X_{i t}+\varepsilon_{i t}
\end{gathered}
$$

A significantly positive coefficient on $N E G_{i t}$ indicates that IFRS filers recognize large losses more frequently in the IFRS reporting period than they do in the U.S. GAAP reconciliation period.

Because accountants anticipate future losses but not future profits, conservatism encourages companies to report bad news in a timelier manner compared to good news. Accordingly, our second metric for timely loss recognition is the coefficient on the interaction of negative returns and earnings in the regression described in Basu (1997). When comparing foreign firms applying U.S. GAAP and IFRS in the reconciliation (IFRS) period, we estimate equation (9) by pooling observations from the reconciliation (IFRS) period.

$$
\begin{gathered}
E P S_{i t}=U S G A A P_{i t} \times\left[\pi_{0}+\pi_{1} R E T_{i t}+\pi_{2} D U M_{i t}+\pi_{3} R E T_{i t} \times D U M_{i t}\right]+I F R S_{i t} \times\left[\sigma_{0}+\sigma_{l} R E T_{i t}+\sigma_{2} D U M_{i t}\right. \\
\left.+\sigma_{3} R E T_{i t} \times D U M_{i t}\right]+\varepsilon_{i t}
\end{gathered}
$$

where USGAAP (IFRS) is an indicator variable equal to 1 for foreign issuers adopting U.S. GAAP (IFRS) and 0 otherwise. EPS is earnings per share, scaled by beginning-of-year price per share. $R E T$ is stock returns computed over the 12 months ending three months after the firm's fiscal year-end. DUM is an indicator variable equal to 1 if the annual stock return is negative and 0 otherwise.

The dummy variable in equation (9), $D U M_{i t}$, captures the intercept and slope effects for the negative returns sample. A significantly positive coefficient on $R E T_{i t} \times D U M_{i t}$ indicates that earnings are more sensitive to negative returns than to positive returns. Our empirical test is whether $\pi_{3}-\sigma_{3} \neq 0$. A significantly positive difference would suggest that earnings for U.S. GAAP adopters are more timely and concurrently sensitive than IFRS filers when reporting publicly available "bad news" than "good news."

When comparing IFRS adopters in the U.S. GAAP reconciliation and IFRS reporting periods, this paper estimates equation (10) by pooling IFRS firm observations from all sample years.

$$
\begin{gathered}
E P S_{i t}=P R E_{i t} \times\left[\rho_{0}+\rho_{1} R E T_{i t}+\rho_{2} D U M_{i t}+\rho_{3} R E T_{i t} \times D U M_{i t}\right]+P O S T_{i t} \times\left[\omega_{0}+\omega_{1} R E T_{i t}+\omega_{2} D U M_{i t}\right. \\
\left.+\omega_{3} R E T_{i t} \times D U M_{i t}\right]+\varepsilon_{i t}
\end{gathered}
$$

where $P R E_{i t}\left(P O S T_{i t}\right)$ is an indicator variable equal to 1 for observations in the U.S. GAAP reconciliation (IFRS reporting) period, and 0 otherwise. Our empirical test is whether $\rho_{3}-\omega_{3} \neq 0$. A significantly positive difference suggests that IFRS filers reported bad news in a timelier manner before the elimination of the reconciliation requirement.

Ball and Shivakumar (2005) hypothesize a positive but asymmetric correlation between accruals and cash flows in terms of timely recognition of economic losses. The asymmetry arrives because companies are more likely to recognize economic losses on a timely basis. On the other hand, companies are more likely to recognize economic gains when realized. This asymmetry suggests a positive correlation between accruals and cash flows in the case of losses.

Accordingly, our third metric for timely loss recognition is the coefficient on negative cash flows in the regression described in Ball and Shivakumar (2005). When comparing foreign firms applying U.S. GAAP and IFRS in the reconciliation (IFRS) period, we estimate equation (11) by pooling observations from the reconciliation (IFRS) period.

$$
\begin{aligned}
A C_{i t}=U S G A A P_{i t} \times\left[\tau_{0}+\tau_{l} O C F_{i t}\right. & \left.+\tau_{2} I N D_{i t}+\tau_{3} O C F_{i t} \times I N D_{i t}\right]+I F R S_{i t} \times\left[\xi_{0}+\xi_{l} O C F_{i t}+\xi_{2} I N D_{i t}\right. \\
& \left.+\xi_{3} O C F_{i t} \times I N D_{i t}\right]+\varepsilon_{i t}
\end{aligned}
$$


The dummy variable in equation (11), IND $D_{i t}$, is equal to 1 if cash flows from operations are negative; it equals 0 otherwise. The other variables are as defined previously. To the extent that accrued losses are more likely to occur in periods of negative cash flows, we predict a positive incremental coefficient on $O C F_{i t} \times I N D_{i t}$ for negative cash flows. Our empirical tests are whether $\tau_{3}-\xi_{3} \neq 0$. A significantly positive difference suggests that the positive association between accruals and cash flows is greater in the case of losses for U.S. GAAP adopters than for IFRS filers.

When comparing IFRS adopters in the U.S. GAAP reconciliation and IFRS reporting periods, we estimate equation (12) by pooling IFRS firm observations from all sample years.

$$
\begin{aligned}
A C_{i t}=P R E_{i t} \times\left[\delta_{0}+\delta_{1} O C F_{i t}+\delta_{2} I N D_{i t}\right. & \left.+\delta_{3} O C F_{i t} \times I N D_{i t}\right]+P O S T_{i t} \times\left[\eta_{0}+\eta_{1} O C F_{i t}+\eta_{2} I N D_{i t}\right. \\
& \left.+\eta_{3} O C F_{i t} \times I N D_{i t}\right]+\varepsilon_{i t}
\end{aligned}
$$

Our empirical test is whether $\delta_{3}-\eta_{3} \neq 0$. A significantly positive difference suggests that the positive association between accruals and cash flows is greater in the case of losses for IFRS adopters in the U.S. GAAP reconciliation period than in the IFRS reporting regime.

\subsection{Value Relevance}

This paper also examines the value relevance of summary accounting measures, book value of equity and net income. Specifically, by value relevance we refer to the ability of summary accounting measures to reflect the underlying economic value of the firm (i.e., contemporaneous stock prices). Following Barth et al. (2008), we first regress stock prices as of six months after the fiscal year-end, $P_{i t}$, on country and industry fixed effects. We then regress the residuals from this regression, $P^{*}$, on book value of stockholders' equity per share, $B V P S_{i t}$, and net income per share, $N I P S_{i t}$, respectively, for relevant subsamples in both the U.S. GAAP reconciliation and IFRS reporting periods. Specifically, this study examines whether the association between accounting data and share price for U.S. GAAP adopters differs from that for IFRS filers. It also examines whether the association between accounting numbers and share price for IFRS filers in the IFRS reporting period differs from that in the U.S. GAAP reconciliation regime. In addition, this paper investigates whether change in this association for IFRS filers between the two regimes is greater than that for U.S. GAAP adopters. Our first value-relevance metric is based on the $R^{2}$ value from the estimation of the following equation:

$$
P_{i t}^{*}=\theta_{0}+\theta_{1} B V P S_{i t}+\theta_{2} N I P S_{i t}+\varepsilon_{i t}
$$

In addition to the price regressions, we perform analyses like those in Ball, Kothari, and Robin (2000). Specifically, we regress net income per share on stock returns separately for "bad news" and "good news" firms, with observations classified as "bad news" for negative returns and "good news" otherwise. As with the first value relevance metric, we first regress net income per share divided by beginning-of-year price, $E P S_{i t}$, on country and industry fixed effects. We then regress the residuals from this regression, $E P S_{i t}^{*}$, on stock returns computed over the 12 months ending three months after the firm's fiscal year-end, $R E T_{i t}$. Our second and third value-relevance metrics are based on the $R^{2}$ values from the estimation of the following equation for "good news" and "bad news" firms:

$$
E P S_{i t}^{*}=\gamma_{0}+\gamma_{1} R E T_{i t}+\varepsilon_{i t}
$$

We estimate equation (14) to determine whether the relation between reported earnings and stock returns for U.S. GAAP adopters differs from that for IFRS filers, and whether the earnings-returns association for IFRS filers in the IFRS reporting period differs from that in the reconciliation regime. Moreover, this paper investigates whether change in this association for IFRS filers between the two regimes is greater than that for U.S. GAAP adopters.

\section{Data}

\subsection{Sample Selection and Data Collection}

Our sample begins with all foreign firms on Amex, Nasdaq, or NYSE during 2004-2010. We identify each foreign firm's accounting standards via the SEC EDGAR and Worldscope databases. Obtaining data beginning in 2004 provides us with a minimum of three years of data from the U.S. GAAP reconciliation period and the IFRS reporting period, respectively. Financial institutions are removed from the sample because their characteristics likely differ from nonfinancial firms, and because the motivation to manage earnings is unclear relative to unregulated industries (Reitenga, Buchheit, Yin, \& Baker, 2002). Firms must also use December 31 as their year-end to eliminate potential bias associated with varying economic circumstances. We also exclude observations in bankruptcy, reorganization, 
and start-up, and we exclude companies with changes in fiscal year-end during the sample period. Given that the SEC's new rule applies for fiscal years ending after November 15, 2007, and interim periods after the effective date, we exclude observations occurring in 2007. Because the analyses contain variables measured using lagged data, this selection process avoids intermingling financial data from both regimes within a single observation and thereby results in better model specifications. Accordingly, observations falling within the sample period 2004-2006 constitute the U.S. GAAP reconciliation sample, and observations occurring in the sample period 2008-2010 constitute the IFRS reporting sample. The analyses use only one randomly selected observation per firm per regime to reduce potential autocorrelation between our observations.

The metrics of accounting quality may reflect the effects of the economic environment that are not attributable to the financial reporting system. To mitigate these effects, we use a matching procedure to select the foreign issuers that comply with U.S. GAAP reconciliations. We first identify the industry and adoption year for each foreign issuer that adopts IFRS. We then identify foreign firms that file U.S. GAAP reconciliations (U.S. GAAP firms) in any sample year that are also in industries with at least one IFRS firm. We match U.S. GAAP firms with IFRS firms by industry and by equity market value. Once a U.S. GAAP firm is a match, it is not a potential match for other IFRS firms.

The final sample includes 260 firm-year observations for 130 firms, of which 65 firms adopt IFRS after the SEC waived the U.S. GAAP reconciliation requirement and 65 firms do not. Table 1 presents the country breakdown of the sample. In general, the sample is from many countries, with greatest representation from the United Kingdom, Israel, and China. We collect relevant financial data from Datastream.

Table 1. Distribution of sample firms

\begin{tabular}{|c|c|c|c|c|c|c|}
\hline Country Breakdown & $\begin{array}{c}\text { Number of } \\
\text { Firm-Year } \\
\text { Observations }\end{array}$ & $\begin{array}{l}\text { Percentage of } \\
\text { Firm-Year } \\
\text { Observations }\end{array}$ & $\begin{array}{l}\text { Number of Firms } \\
\text { Applying U.S. } \\
\text { GAAP }\end{array}$ & $\begin{array}{c}\text { Percentage of } \\
\text { Firms Applying } \\
\text { U.S. GAAP }\end{array}$ & $\begin{array}{l}\text { Number of Firms } \\
\text { Adopting IFRS }\end{array}$ & $\begin{array}{c}\text { Percentage of } \\
\text { Firms Adopting } \\
\text { IFRS }\end{array}$ \\
\hline Antigua & 6 & 2.31 & 6 & 3.08 & 0 & 0.00 \\
\hline Argentina & 4 & 1.54 & 4 & 2.05 & 0 & 0.00 \\
\hline Australia & 6 & 2.31 & 3 & 1.54 & 3 & 4.62 \\
\hline Bermuda & 6 & 2.31 & 5 & 2.56 & 1 & 1.54 \\
\hline Brazil & 16 & 6.15 & 16 & 8.21 & 0 & 0.00 \\
\hline British Virgin Islands & 8 & 3.08 & 8 & 4.10 & 0 & 0.00 \\
\hline Cayman Islands & 12 & 4.62 & 12 & 6.15 & 0 & 0.00 \\
\hline Chile & 10 & 3.85 & 7 & 3.59 & 3 & 4.62 \\
\hline China & 24 & 9.23 & 12 & 6.15 & 12 & 18.46 \\
\hline Denmark & 6 & 2.31 & 3 & 1.54 & 3 & 4.62 \\
\hline Finland & 2 & 0.77 & 1 & 0.51 & 1 & 1.54 \\
\hline France & 4 & 1.54 & 3 & 1.54 & 1 & 1.54 \\
\hline Germany & 2 & 0.77 & 1 & 0.51 & 1 & 1.54 \\
\hline Hong Kong & 8 & 3.08 & 4 & 2.05 & 4 & 6.15 \\
\hline Ireland & 6 & 2.31 & 3 & 1.54 & 3 & 4.62 \\
\hline Israel & 32 & 12.31 & 25 & 12.82 & 7 & 10.77 \\
\hline Liberia & 6 & 2.31 & 6 & 3.08 & 0 & 0.00 \\
\hline Luxembourg & 6 & 2.31 & 3 & 1.54 & 3 & 4.62 \\
\hline Marshall Islands & 2 & 0.77 & 2 & 1.03 & 0 & 0.00 \\
\hline Mexico & 10 & 3.85 & 9 & 4.62 & 1 & 1.54 \\
\hline Netherlands & 4 & 1.54 & 3 & 1.54 & 1 & 1.54 \\
\hline New Zealand & 2 & 0.77 & 1 & 0.51 & 1 & 1.54 \\
\hline Russian Federation & 10 & 3.85 & 10 & 5.13 & 0 & 0.00 \\
\hline South Africa & 12 & 4.62 & 6 & 3.08 & 6 & 9.23 \\
\hline South Korea & 16 & 6.15 & 15 & 7.69 & 1 & 1.54 \\
\hline Taiwan & 8 & 3.08 & 8 & 4.10 & 0 & 0.00 \\
\hline Turkey & 4 & 1.54 & 2 & 1.03 & 2 & 3.08 \\
\hline United Kingdom & 28 & 10.77 & 17 & 8.72 & 11 & 16.92 \\
\hline Total & 260 & 100.00 & 195 & 100.00 & 65 & 100.00 \\
\hline
\end{tabular}

This table presents the country breakdown for sample firms. Given that the SEC's new rule applies to financials statements issued for fiscal years ending after November 15, 2007, and interim periods after the effective date, we exclude observations occurring in 2007. Accordingly, observations falling within the sample period 2004-2006 are in the U.S. GAAP reconciliation sample, and observations occurring in the sample period 2008-2010 are in the IFRS reporting sample. 


\subsection{Descriptive Statistics}

Table 2 presents descriptive statistics relating to variables in the analyses. The results show that foreign firms adopting IFRS exhibit lower changes in net income and net cash flow than do foreign issuers filing U.S. GAAP reconciliations. Foreign firms complying with U.S. GAAP reconciliations have higher growth than IFRS filers (the mean but not median difference is significant). There is some evidence that IFRS firms are more likely to issue debt (the mean but not median difference is significant). Further, foreign firms applying IFRS are more likely to be audited by one of the largest auditing firms and trade on more exchanges than those filing U.S. GAAP reconciliations, although both differences are insignificant.

\section{Results}

\subsection{IFRS Reporting Period}

To address RQ1, Table 3 presents results comparing the quality of accounting for U.S. GAAP reconciliations and IFRS filers in the IFRS reporting period. It reveals that foreign firms applying IFRS generally demonstrate more earnings management, less timely loss recognition, and more value relevance of accounting amounts than do firms filing U.S. GAAP reconciliations.

The first two findings pertaining to earnings management indicate that foreign issuers adopting IFRS exhibit a significantly lower variability of change in net income, $\Delta N I^{*}(0.002$ versus 0.013$)$, and a significantly lower ratio of the variance of change in net income, $\triangle N I^{*}$, to the variance of change in cash flow, $\triangle O C F^{*}$ (0.333 versus 1.300$)$. This suggests that IFRS firms smooth earnings more than their counterparts. The third finding shows that the correlation between accruals $\left(A C^{*}\right)$ and cash flow $\left(O C F^{*}\right)$ for IFRS firms is more negative than for firms filing U.S. GAAP reconciliations $(-0.138$ versus -0.075 , respectively), although the difference is insignificant. Last, the coefficient on POS, 20.372, is positive, although not significantly so, which suggests that IFRS firms more frequently report small positive income, consistent with managing earnings toward an earnings target.

The next finding in Table 3 relates to timely loss recognition. The coefficient on $N E G, 0.730$, is insignificantly different from zero in the IFRS reporting period, which suggests that the IFRS firms do not recognize losses on a timelier basis than their counterparts in the IFRS reporting period. Based on Ball, Kothari, and Robin (2000), as well as Basu (1997), a positive coefficient on return, RET, interacted with the dummy variable DUM (if the return is negative) indicates conservatism. The significantly positive coefficient on $R E T \times D U M, 0.351$, indicates that foreign issuers filing U.S. GAAP reconciliations are conservative. U.S. GAAP firms also demonstrate a higher level of conservatism than IFRS filers, although the difference is insignificant.

The other finding pertaining to timely loss recognition is the coefficient on negative cash flows in the regression described in Ball and Shivakumar (2005). The significantly positive coefficient on cash flow, $O C F$, interacted with the indicator variable $I N D$ (if cash flow from operating activities is negative) for foreign firms applying U.S. GAAP reconciliations and IFRS ( 0.821 and 0.601 , respectively) suggest that positive correlation between cash flows and accruals is greater in the case of losses for both groups of firms. Although we find that both samples of foreign firms recognize economic losses on a timely basis, U.S. GAAP firms demonstrate a higher level of conservatism than IFRS filers as measured by this coefficient.

The final set of findings in Table 3 relates to the value relevance of accounting amounts. First, regressions of price on net income and equity book value for foreign firms applying IFRS or filing U.S. GAAP reconciliations reveal that the $R^{2}$ value for IFRS firms is significantly greater than that for their counterparts: $39.6 \%$ versus $12.8 \%$. The $R^{2}$ value for IFRS firms reporting good news is greater than that for U.S. GAAP firms reporting good news $(11.7 \%$ versus $7.1 \%$ ), although the difference is insignificant. In addition, the $R^{2}$ value for IFRS firms reporting bad news is significantly greater than that for U.S. GAAP firms reporting bad news (47.2\% versus $17.1 \%)$. The combined evidence suggests that accounting amounts are more value relevant for foreign issuers applying IFRS than for firms filing U.S. GAAP reconciliations in the IFRS reporting period.

\subsection{U.S. GAAP Reconciliation Period}

To address RQ2, Table 4 presents findings for earnings management, timely loss recognition, and value relevance for foreign issuers complying with U.S. GAAP reconciliations or IFRS in the U.S. GAAP reconciliation period. It reveals that the two groups of firms exhibit no significant differences in accounting quality in the U.S. GAAP reconciliation period. Accordingly, differences in accounting quality between the two types of foreign firms in the U.S. GAAP reconciliation period generally do not explain the IFRS reporting-period differences. 
Table 2. Descriptive statistics relating to variables used in analyses

\begin{tabular}{|c|c|c|c|c|c|c|}
\hline \multirow[b]{2}{*}{ Test Variables } & \multicolumn{3}{|c|}{ U.S. GAAP $(\mathrm{N}=130)$} & \multicolumn{3}{|c|}{ IFRS $(\mathrm{N}=130)$} \\
\hline & Mean & Median & $\begin{array}{l}\text { Standard } \\
\text { Deviation }\end{array}$ & Mean & Median & $\begin{array}{l}\text { Standard } \\
\text { Deviation }\end{array}$ \\
\hline$\Delta N I$ & 0.0026 & 0.0033 & 0.1185 & $-0.0172^{*}$ & $-0.0083^{* *}$ & 0.0498 \\
\hline$\triangle O C F$ & 0.0066 & 0.0034 & 0.1241 & $-0.0171^{*}$ & $-0.0151^{* * *}$ & 0.0600 \\
\hline$A C$ & -0.0282 & -0.0280 & 0.0638 & -0.0255 & -0.0187 & 0.0667 \\
\hline$O C F$ & 0.1112 & 0.1109 & 0.0122 & 0.0955 & 0.1113 & 0.0120 \\
\hline$P O S$ & 0.0000 & 0.0000 & 0.0270 & 0.0100 & 0.0000 & 0.0880 \\
\hline$N E G$ & 0.0500 & 0.0000 & 0.2110 & 0.0500 & 0.0000 & 0.2110 \\
\hline$E P S$ & 0.0575 & 0.0497 & 0.1589 & 0.0721 & 0.0552 & 0.5089 \\
\hline$R E T$ & 0.2319 & 0.0416 & 1.2050 & 0.5041 & 0.1203 & 1.5718 \\
\hline$R E T \times D U M$ & -0.1743 & 0.0000 & 0.2472 & -0.1286 & 0.0000 & 0.2336 \\
\hline$O C F \times I N D$ & -0.0161 & 0.0000 & 0.0729 & -0.0191 & 0.0000 & 0.0881 \\
\hline$P$ & 23.0140 & 19.745 & 18.3046 & 27.0826 & 18.2000 & 24.2058 \\
\hline$B V P S$ & 11.2832 & 9.5090 & 8.7650 & 10.5080 & 8.2550 & 8.4562 \\
\hline NIPS & 1.0680 & 0.9630 & 1.6398 & 1.4691 & 1.2300 & 2.4741 \\
\hline \multicolumn{7}{|c|}{ Control Variables } \\
\hline SIZE & 7.7222 & 7.9073 & 2.2189 & 7.7152 & 7.9307 & 2.2529 \\
\hline GROWTH & 0.3305 & 0.1640 & 0.8132 & $0.1516^{* *}$ & 0.1333 & 0.2436 \\
\hline$C S$ & 0.1318 & 0.0327 & 0.3030 & 0.1799 & 0.0256 & 0.5792 \\
\hline$L E V$ & 1.0956 & 0.8417 & 0.9435 & $1.3690^{*}$ & 0.9651 & 1.4402 \\
\hline$T L$ & 0.4452 & 0.1039 & 1.5723 & 0.3010 & 0.0954 & 0.7562 \\
\hline SALES & 0.5951 & 0.5047 & 0.4695 & 0.5937 & 0.5672 & 0.2919 \\
\hline$A U D$ & 0.9000 & 1.0000 & 0.3030 & 0.9400 & 1.0000 & 0.2420 \\
\hline NUMEX & 1.6200 & 1.0000 & 1.0430 & 1.6700 & 1.0000 & 0.8320 \\
\hline
\end{tabular}

$\triangle N I$ is the change in annual net income, where net income is divided by end-of-year total assets; $\triangle O C F$ is the change in annual net cash flow, $O C F$, where cash flow is divided by end-of-year total assets; $A C$ is net income less net cash flows from operating activities, divided by end-of-year total assets; $O C F$ is annual net cash flow from operating activities, divided by end-of-year total assets; $P O S$ is an indicator variable equal to 1 if annual net income deflated by total assets is between 0 and 0.01 , and 0 otherwise; $N E G$ is an indicator variable equal to 1 if annual net income scaled by total assets is less than -0.20 , and 0 otherwise; EPS is earnings per share divided by beginning-of-year price; RET is stock returns computed over the 12 months ending three months after the firm's fiscal year-end; DUM is an indicator variable equal to 1 if the annual stock return is negative, and 0 otherwise; IND is an indicator variable equal to 1 if annual net cash flow from operating activities is negative, and 0 otherwise; $P$ is price as of six months after fiscal year-end; BVPS is book value of equity per share; NIPS is net income per share.

SIZE is the natural logarithm of end-of-year market value of equity in millions of dollars; GROWTH is annual percentage change in sales; $C S$ is annual percentage change in common stock; $L E V$ is end-of-year total liabilities divided by end-of-year book value of equity; $T L$ is annual percentage change in total liabilities; SALES is sales divided by end-of-year total assets; $A U D$ is an indicator variable equal to 1 if the firm's auditor is among the big-four accounting firms, and 0 otherwise; NUMEX is the number of exchange listings.

$*, * *, * * *$ indicate significant difference between the U.S. GAAP and IFRS firms at the $0.10,0.05$, and 0.10 levels, respectively (two-tailed). 
Table 3. Comparison of U.S. GAAP and IFRS firms' accounting quality in the period after the elimination of the reconciliation requirement

\begin{tabular}{lcc}
\hline Earnings-Management & U.S. GAAP & IFRS \\
Metric & $(\mathrm{N}=65)$ & $(\mathrm{N}=65)$ \\
\hline Variability of $\triangle N I^{*}$ & 0.013 & $0.002^{* * *}$ \\
Variability of $\triangle N I^{*}$ over $\triangle O C F^{*}$ & 1.300 & $0.333^{* * *}$ \\
Correlation of $A C^{*}$ and $O C F^{*}$ & -0.075 & -0.138 \\
Small Positive $N I(P O S)$ & & \\
Timely Loss-Recognition & & 20.372 \\
Metric & & \\
\hline Large Negative $N I(N E G)$ & & 0.730 \\
Basu $R E T \times D U M$ Coefficient & $0.351^{++}$ & 0.106 \\
Ball-Shivakumar $O C F \times I N D$ Coefficient & $0.821^{+++* *}$ & $0.601^{+++}$ \\
Value Relevance & & \\
Regression $R^{2}$ & & \\
\hline Price & & \\
Good News & 0.128 & $0.396^{* *}$ \\
Bad News & 0.071 & $0.472^{* * *}$
\end{tabular}

We base the analysis on regressions including controls defined in Table 2 . We define the variability of $\triangle N I^{*}\left(\triangle O C F^{*}\right)$ as the variance of residuals from a regression of $\triangle N I(\triangle O C F)$ on the control variables, and the variability of $\triangle N I^{*}$ over $\triangle O C F^{*}$ as the ratio of the variability of $\triangle N I^{*}$ divided by the variability of $\triangle O C F^{*}$. Correlation of $A C^{*}$ and $O C F^{*}$ is the partial Spearman correlation between the residuals from a regression of $A C$ and $O C F$, respectively, on the control variables. $\triangle N I, \triangle O C F, A C$, and $O C F$ are defined in Table 2.

For small positive (large negative) $N I$, we estimate a separate logit model for each measure by regressing an indicator variable (that equals 1 for foreign issuers adopting IFRS and 0 for those complying with U.S. GAAP reconciliations) on $P O S(N E G)$ and control variables. $P O S$ (NEG) equals 1 if annual net income deflated by total assets is between 0 and 0.01 (less than -0.20 ), and 0 otherwise; the coefficient on the indicator variable is reported.

The Basu RET $\times D U M$ coefficient is the estimate of $\pi_{3}$ and $\sigma_{3}$ for U.S. GAAP and IFRS observations, respectively, from the following regression: $E P S=U S G A A P \times\left[\pi_{0}+\pi_{1} R E T+\pi_{2} D U M+\pi_{3} R E T \times D U M\right]+I F R S \times\left[\sigma_{0}+\sigma_{1} R E T+\right.$ $\left.\sigma_{2} D U M+\sigma_{3} R E T \times D U M\right]+\varepsilon$, where USGAAP (IFRS) equals 1 for foreign issuers applying U.S. GAAP (IFRS), and 0 otherwise. $D U M$ is an indicator variable equal to 1 if the annual stock return is negative, and 0 otherwise. EPS and RET are defined in Table 2.

The Ball-Shivakumar $O C F \times I N D$ coefficient is the estimate of $\tau_{3}$ and $\xi_{3}$ for U.S. GAAP and IFRS observations, respectively, from the following regression: $A C=U S G A A P \times\left[\tau_{0}+\tau_{l} O C F+\tau_{2} I N D+\tau_{3} O C F \times I N D\right]+I F R S \times\left[\xi_{0}+\right.$ $\left.\xi_{I} O C F+\xi_{2} I N D+\xi_{3} O C F \times I N D\right]+\varepsilon . I N D$ equals 1 if cash flows from operations is negative, and 0 otherwise. USGAAP and IFRS are defined as above, and $A C$ and $O C F$ are defined in Table 2.

The price regression is based on a two-stage regression. In the first stage, $P$ is regressed on industry and country fixed-effect indicator variables, where $P$ is price as of six months after the fiscal year-end. The second-stage regression is $P^{*}=\theta_{0}+\theta_{1} B V P S+\theta_{2} N I P S+\varepsilon$, where $P^{*}$ is the residual from the first-stage regression. BVPS and NIPS are defined in Table 2. The good-/bad-news regression is based on a two-stage regression. In the first stage, EPS is regressed on industry and country fixed-effect indicator variables. The second-stage regression is $E P S^{*}=\gamma_{0}+\gamma_{1} R E T$ $+\varepsilon$, where $E P S^{*}$ is the residual from the first-stage regression, and EPS and RET are defined in Table 2. Good-news (bad-news) observations are those for which $R E T$ is nonnegative (negative). $R^{2}$ is from the second-stage regressions.

${ }^{*},{ }^{* *}$, and ${ }^{* * *}$ indicate significant difference between the U.S. GAAP and IFRS firms at the $0.10,0.05$, and 0.10 levels, respectively (two-tailed).

${ }^{+},{ }^{++}$, and ${ }^{+++}$indicate significantly different from zero at the $0.10,0.05$, and 0.10 levels, based on a one-sided alternative for signed predictions, and on a two-sided alternative otherwise. 
The first finding relating to earnings management indicates that before the elimination of the reconciliation requirement, IFRS firms exhibit an insignificantly lower variance of the change in net income than do foreign issuers filing U.S. GAAP reconciliations $\left(\Delta N I^{*}=0.003\right.$ versus 0.004$)$. These results suggest that the lower $\Delta N I^{*}$ variance for IFRS firms in Table 3 in the IFRS reporting period is not a result of a lower $\Delta N I^{*}$ variance for IFRS firms in the U.S. GAAP reconciliation period.

The second finding shows that the ratio of the variance of change in net income $\left(\Delta N I^{*}\right)$ to the variance of the change in cash flow $\left(\triangle O C F^{*}\right)$ is insignificantly lower for IFRS firms than for their counterparts (0.893 versus 1.053$)$. These findings contrast with the results for the IFRS reporting period, in which foreign firms adopting IFRS have a significantly lower ratio of the two variances.

The third finding indicates that the correlation between accruals $\left(A C^{*}\right)$ and cash flow $\left(O C F^{*}\right)$ is insignificantly less negative for IFRS firms than for U.S. GAAP firms $(-0.340$ versus -0.345$)$. This finding also contrasts with the finding for the IFRS reporting period, in which IFRS firms have a more negative correlation between accruals and cash flows, although the difference is insignificant.

Finally, the coefficient on POS, -0.025 , is insignificantly different from zero in the U.S. GAAP reconciliation period, which suggests that the two groups of foreign firms report small positive net income with frequencies that do not differ in the U.S. GAAP reconciliation period.

The next finding in Table 4 relates to the timeliness of loss recognition. The coefficient on NEG, -1.282 , is insignificantly different from zero in the U.S. GAAP reconciliation period, which suggests that the IFRS firms do not recognize losses more frequently than their counterparts in the U.S. GAAP reconciliation period. Further, based on Ball, Kothari, and Robin (2000), as well as Basu (1997), the insignificant coefficient on RET $\times$ DUM indicates that the two groups do not exhibit significant differences in conservatism. In addition, based on Ball and Shivakumar (2005), the results indicate that foreign firms applying U.S. GAAP or IFRS recognize economic losses on a timely basis as suggested by the significantly positive coefficient on $O C F \times I N D, 0.671$ and 0.657 , respectively. However, the two groups of firms do not exhibit significant differences in the level of conservatism.

The final set of findings in Table 4 relates to the association of stock prices with accounting data. Regressions of price on net income and equity book value indicate that the $R^{2}$ value for foreign firms adopting IFRS is insignificantly larger than that for firms filing U.S. GAAP reconciliations, $(31.9 \%$ versus $28.4 \%)$ in the period before the SEC allows IFRS financial statements. In the IFRS reporting period, this $R^{2}$ value is significantly larger for IFRS firms. These findings suggest that the higher value relevance for IFRS firms as evidenced by the price regressions in the IFRS reporting period is not attributable to higher value relevance in the U.S. GAAP reconciliation period. The $R^{2}$ value from a regression of net income on returns for good-news (bad-news) IFRS firms, $8.6 \%(0.7 \%)$, is insignificantly smaller (larger) than that for good-news (bad-news) U.S. GAAP firms, $17.4 \%(0.6 \%)$, suggesting that there are no value relevance differences between the two types of foreign issuers in the U.S. GAAP reconciliation period. This finding contrasts with the results for the IFRS reporting period, in which the $R^{2}$ value for IFRS firms reporting bad news is significantly greater than that for U.S. GAAP firms reporting bad news.

\subsection{Comparison of the IFRS Reporting and U.S. GAAP Reconciliation Periods for IFRS Firms}

To address RQ3, Table 5 presents a comparison of the quality metrics for IFRS firms before and after the SEC permitted IFRS in financial reporting. Tests of the earnings-management metrics show a deterioration in accounting quality with application of IFRS. Specifically, the variability of change in net income decreases significantly from 0.003 to 0.002 , and the variability of change in net income relative to the variability of the change in cash flow also decreases significantly, from 0.893 to 0.333 . The correlation between accruals and cash flows in the IFRS reporting period, -0.138 , is less negative than that in the U.S. GAAP reconciliation period, -0.340 , but insignificantly so. Similarly, as the POS coefficient of 19.989 indicates, the frequency of small positive net income increases after foreign firms are allowed to issue financial reports under IFRS, although this increase is insignificant.

As the insignificant $N E G$ coefficient of 0.527 indicates, IFRS firms do not exhibit significant differences in the frequency of large negative net income before and after the SEC requirement changed. Table 5 also reveals the insignificant coefficient on $R E T \times D U M$, which suggests that the IFRS firms across the two regimes do not exhibit significant differences in conservatism. Moreover, the significantly positive coefficient on $O C F \times I N D$ suggests that IFRS firms recognize economic losses on a timely basis in the U.S. GAAP reconciliation and IFRS reporting regimes ( 0.657 and 0.601 , respectively), although the difference is insignificant. The combined evidence suggests that the SEC's waiver of the reconciliation requirement did not change the level of conservatism among IFRS firms. 
Table 4. Comparison of U.S. GAAP and IFRS firms' accounting quality in the period before the elimination of the reconciliation requirement

\begin{tabular}{lcc}
\hline $\begin{array}{l}\text { Earnings-Management } \\
\text { Metric }\end{array}$ & $\begin{array}{c}\text { U.S. GAAP } \\
(\mathrm{N}=65)\end{array}$ & $\begin{array}{c}\text { IFRS } \\
(\mathrm{N}=65)\end{array}$ \\
\hline Variability of $\triangle N I^{*}$ & 0.004 & 0.003 \\
Variability of $\triangle N I^{*}$ over $\triangle O C F^{*}$ & 1.053 & 0.893 \\
Correlation of $A C^{*}$ and $O C F^{*}$ & -0.345 & -0.340 \\
Small positive $N I(P O S)$ & & -0.025 \\
Timely Loss-Recognition & & \\
Metric & & \\
\hline Large Negative $N I(N E G)$ & & -1.282 \\
Basu $R E T \times D U M$ Coefficient & 0.100 & \\
Ball-Shivakumar $O C F \times I N D$ Coefficient & $0.671^{+++}$ & 0.337 \\
Value Relevance & & $0.657^{++}$ \\
Regression $R^{2}$ & & \\
\hline Price & & \\
Good News & 0.284 & 0.319 \\
Bad News & 0.174 & 0.086 \\
\hline
\end{tabular}

We base the analysis on regressions including controls defined in Table 2 . We define the variability of $\triangle N I^{*}\left(\triangle O C F^{*}\right)$ as the variance of residuals from a regression of $\triangle N I(\triangle O C F)$ on the control variables, and the variability of $\triangle N I^{*}$ over $\triangle O C F^{*}$ as the ratio of the variability of $\triangle N I^{*}$ divided by the variability of $\triangle O C F^{*}$. Correlation of $A C^{*}$ and $O C F^{*}$ is the partial Spearman correlation between the residuals from a regression of $A C$ and $O C F$, respectively, on the control variables. $\triangle N I, \triangle O C F, A C$, and $O C F$ are defined in Table 2.

For small positive (large negative) $N I$, we estimate a separate logit model for each measure by regressing an indicator variable (that equals 1 for foreign issuers adopting IFRS and 0 for those complying with U.S. GAAP reconciliations) on $P O S(N E G)$ and control variables. POS (NEG) equals 1 if annual net income deflated by total assets is between 0 and 0.01 (less than -0.20), and 0 otherwise; the coefficient on the indicator variable is reported.

The Basu RET $\times D U M$ coefficient is the estimate of $\pi_{3}$ and $\sigma_{3}$ for U.S. GAAP and IFRS observations, respectively, from the following regression: EPS $=U S G A A P \times\left[\pi_{0}+\pi_{1} R E T+\pi_{2} D U M+\pi_{3} R E T \times D U M\right]+I F R S \times\left[\sigma_{0}+\sigma_{1} R E T+\right.$ $\left.\sigma_{2} D U M+\sigma_{3} R E T \times D U M\right]+\varepsilon$, where USGAAP (IFRS) equals 1 for foreign issuers applying U.S. GAAP (IFRS), and 0 otherwise. $D U M$ is an indicator variable equal to 1 if the annual stock return is negative, and 0 otherwise. EPS and RET are defined in Table 2.

The Ball-Shivakumar $O C F \times I N D$ coefficient is the estimate of $\tau_{3}$ and $\xi_{3}$ for U.S. GAAP and IFRS observations, respectively, from the following regression: $A C=U S G A A P \times\left[\tau_{0}+\tau_{1} O C F+\tau_{2} I N D+\tau_{3} O C F \times I N D\right]+I F R S \times\left[\xi_{0}+\right.$ $\left.\xi_{1} O C F+\xi_{2} I N D+\xi_{3} O C F \times I N D\right]+\varepsilon$. IND equals 1 if cash flows from operations is negative, and 0 otherwise. $U S G A A P$ and IFRS are defined as above, and $A C$ and $O C F$ are defined in Table 2.

The price regression is based on a two-stage regression. In the first stage, $P$ is regressed on industry and country fixed-effect indicator variables, where $P$ is price as of six months after the fiscal year-end. The second stage regression is $P^{*}=\theta_{0}+\theta_{1} B V P S+\theta_{2}$ NIPS $+\varepsilon$, where $P^{*}$ is the residual from the first-stage regression. BVPS and NIPS are defined in Table 2. The good-/bad-news regression is based on a two-stage regression. In the first stage, EPS is regressed on industry and country fixed-effect indicator variables. The second-stage regression is $E P S^{*}=\gamma_{0}+\gamma_{1} R E T$ $+\varepsilon$, where $E P S^{*}$ is the residual from the first-stage regression, and EPS and RET are defined in Table 2. Good-news (bad-news) observations are those for which RET is nonnegative (negative). $R^{2}$ is from the second-stage regressions.

${ }^{*},{ }^{* *}$, and ${ }^{* * *}$ indicate significant difference between the U.S. GAAP and IFRS firms at the $0.10,0.05$, and 0.10 levels, respectively (two-tailed).

${ }^{+},{ }^{++}$, and ${ }^{++}$indicate significantly different from zero at the $0.10,0.05$, and 0.10 levels, based on a one-sided alternative for signed predictions, and on a two-sided alternative otherwise. 
The $R^{2}$ values from the price regressions and from the good- and bad-news returns regressions increase from $31.9 \%$, $8.6 \%$, and $0.7 \%$ in the U.S. GAAP reconciliation period to $39.6 \%, 11.7 \%$, and $47.2 \%$ in the IFRS reporting period, respectively, although the increase is significant only for the bad-news regression. The results suggest that accounting amounts are more value relevant for foreign issuers applying IFRS after the SEC waived the U.S. GAAP reconciliation requirement.

\subsection{Difference in Changes for U.S. GAAP and IFRS Firms}

Overall, the results indicate that accounting quality in terms of earnings management and the timeliness of loss recognition for foreign issuers applying IFRS deteriorates from the U.S. GAAP reconciliation to the IFRS reporting period. The results also suggest that accounting quality for foreign issuers applying IFRS is lower than that for firms filing U.S. GAAP reconciliations in the IFRS reporting period but is not different from that for their counterparts in the U.S. GAAP reconciliation period. However, the results also show that accounting quality in terms of value relevance for IFRS firms improves from the U.S. GAAP reconciliation to the IFRS reporting periods and is greater than that for firms filing U.S. GAAP reconciliations after the elimination of the reconciliation requirement. However, it is not different from that for their counterparts in the U.S. GAAP reconciliation period. Accordingly, our final analysis examines whether changes in accounting quality for IFRS firms between the U.S. GAAP reconciliation and IFRS reporting periods is different from that for firms filing U.S. GAAP reconciliations.

To answer RQ4, the results in Table 6 document that foreign firms filing U.S. GAAP reconciliations improve the quality of their accounting. They engage in less earnings smoothing and recognize losses more quickly than do foreign issuers adopting IFRS between the U.S. GAAP reconciliation and IFRS reporting periods. However, only differences in changes for two of the four earnings-management metrics (i.e., the variability of $\Delta N I^{*}$ and the ratio of the variance of change in net income, $\triangle N I^{*}$, to the variance of change in cash flow, $\triangle O C F^{*}$ ) and two of the three timely loss-recognition metrics (coefficients on $R E T \times D U M$ and $O C F \times I N D$ ) are significant.

On the other hand, firms applying IFRS experience a greater improvement in accounting quality in terms of value relevance than do firms filing U.S. GAAP reconciliations between the two regimes. All of the three $R^{2}$ metrics for IFRS firms are significantly greater than those for their counterparts.

\section{Additional Analyses}

\subsection{Alternative Significance Tests}

A potential problem with statistical inferences in small samples is the validity of the normal distribution assumption (Hung \& Subramanyam, 2007). To address this issue, we apply the bootstrapping methods, which are resampling techniques for assessing uncertainties, to the estimations of the regression models in Tables 3 through 6 (see Efron \& Tibshirani, 1993). Specifically, we bootstrap the residuals, construct 1,000 random samples, and assess the 5\% and $95 \%$ confidence limits based on 1,000 random parameter estimates. Likewise, we test for differences in each metric based on an empirical distribution of the differences obtained from a bootstrapping procedure. An advantage of the bootstrapping approach is that it requires no assumptions about the distribution of each metric. Untabulated results reveal the same inferences as the findings in the aforementioned tables.

\subsection{Controlling for Self-selection Bias}

Non-U.S. firms voluntarily adopt IFRS do not represent a random selection after the SEC waived the U.S. GAAP reconciliation requirement for foreign issuers registered in the U.S. To ensure that self-selection will not drive our findings, we adopt the Heckman two-stage selection model for the samples firms. In the first stage, we use a probit model to analyze the sample firms' decision to adopt IFRS. The dependent variable in the model equals 1 for an IFRS adopter and 0 for a U.S. GAAP filer. Following prior studies (Harris \& Muller, 1999; Hung \& Subramanyam, 2007; Leuz, 2003), this paper predicts that the decision to adopt IFRS is a function of the following factors: (1) profitability, measured as return on assets, (2) leverage, measured as total liabilities divided by book value of equity, (3) firm size, measured as the natural logarithm of the market value of equity, (4) financing needs, measured by an increase in common stock or long-term debt, and (5) industry classification, measured as indicator variables based on 2-digit SIC codes.

Specifically, we begin by estimating the following probit model:

$$
S E L E C T_{i t}=\alpha_{0}+\alpha_{1} R O A_{i t}+\alpha_{2} L E V_{i t}+\alpha_{3} S I Z E_{i t}+\alpha_{4} C S_{i t}+\alpha_{5} D E B T_{i t}+\alpha_{m}(\Sigma I N D)+\varepsilon_{i t}
$$


Table 5. Comparison of IFRS firms' accounting quality before and after the elimination of the reconciliation requirement

\begin{tabular}{lcc}
\hline Earnings-Management & PRE & POST \\
Metric & $(\mathrm{N}=65)$ & $(\mathrm{N}=65)$ \\
\hline Variability of $\triangle N I^{*}$ & 0.003 & $0.002^{*}$ \\
Variability of $\triangle N I^{*}$ over $\triangle O C F^{*}$ & 0.893 & $0.333^{* * *}$ \\
Correlation of $A C^{*}$ and $O C F^{*}$ & -0.340 & -0.138 \\
Small Positive $N I(P O S)$ & & \\
Timely Loss-Recognition & & 19.989 \\
Metric & & \\
\hline Large Negative $N I(N E G)$ & & 0.527 \\
Basu $R E T \times D U M$ Coefficient & 0.337 & 0.106 \\
Ball-Shivakumar $O C F \times I N D$ Coefficient & $0.657^{++}$ & $0.601^{+++}$ \\
Value Relevance & & \\
Regression $R^{2}$ & & \\
\hline Price & & \\
Good News & 0.319 & 0.396 \\
Bad News & 0.086 & $0.472^{* * *}$
\end{tabular}

We base the analysis on regressions including controls defined in Table 2 . We define the variability of $\triangle N I^{*}\left(\triangle O C F^{*}\right)$ as the variance of residuals from a regression of $\triangle N I(\triangle O C F)$ on the control variables, and the variability of $\triangle N I^{*}$ over $\triangle O C F^{*}$ as the ratio of the variability of $\triangle N I^{*}$ divided by the variability of $\triangle O C F^{*}$. Correlation of $A C^{*}$ and $O C F^{*}$ is the partial Spearman correlation between the residuals from a regression of $A C$ and $O C F$, respectively, on the control variables. $\triangle N I, \triangle O C F, A C$, and $O C F$ are defined in Table 2.

For small positive (large negative) $N I$, we estimate a separate logit model for each measure by regressing an indicator variable (that equals 1 for observations in the IFRS reporting period and 0 for those in the U.S. GAAP reconciliation period) on $P O S(N E G)$ and control variables. $P O S(N E G)$ equals 1 if annual net income deflated by total assets is between 0 and 0.01 (less than -0.20), and 0 otherwise; the coefficient on the indicator variable is reported.

The Basu RET $\times D U M$ coefficient is the estimate of $\rho_{3}$ and $\omega_{3}$ for the U.S. GAAP reconciliation and IFRS periods, respectively, from the followng regression: $E P S=P R E \times\left[\rho_{0}+\rho_{l} R E T+\rho_{2} D U M+\rho_{3} R E T \times D U M\right]+P O S T \times\left[\omega_{0}+\right.$ $\left.\omega_{1} R E T+\omega_{2} D U M+\omega_{3} R E T \times D U M\right]+\varepsilon$, where PRE (POST) equals 1 for observations occurring in the reconciliation (IFRS) period, and 0 otherwise. $D U M$ equals 1 if the annual stock return is negative, and 0 otherwise. EPS and RET are defined in Table 2.

The Ball-Shivakumar $O C F \times I N D$ coefficient is the estimate of $\delta_{3}$ and $\eta_{3}$ for the the U.S. GAAP reconciliation and IFRS periods, respecitively, from the following regression: $A C=P R E \times\left[\delta_{0}+\delta_{1} O C F+\delta_{2} I N D+\delta_{3} O C F \times I N D\right]+$ $P O S T \times\left[\eta_{0}+\eta_{1} O C F+\eta_{2} I N D+\eta_{3} O C F \times I N D\right]+\varepsilon . I N D$ equals 1 if cash flows from operations is negative, and 0 otherwise. PRE, and POST are defined as above, and $A C$ and $O C F$ are defined in Table 2.

The price regression is based on a two-stage regression. In the first stage, $P$ is regressed on industry and country fixed-effect indicator variables, where $P$ is price as of six months after the fiscal year-end. The second-stage regression is $P^{*}=\theta_{0}+\theta_{1} B V P S+\theta_{2} N I P S+\varepsilon$, where $P^{*}$ is the residual from the first-stage regression. BVPS and NIPS are defined in Table 2. The good-/bad-news regression is based on a two-stage regression. In the first stage, EPS is regressed on industry and country fixed-effect indicator variables. The second-stage regression is $E P S^{*}=\gamma_{0}+\gamma_{1} R E T$ $+\varepsilon$, where $E P S^{*}$ is the residual from the first-stage regression, and EPS and RET are defined in Table 2. Good-news (bad-news) observations are those for which $R E T$ is nonnegative (negative). $R^{2}$ is from the second-stage regressions.

${ }^{*},{ }^{* *}$, and ${ }^{* * *}$ indicate significant difference between the U.S. GAAP and IFRS firms at the $0.10,0.05$, and 0.10 levels, respectively (one-tailed).

${ }^{+},{ }^{++}$, and ${ }^{++}$indicate significantly different from zero at the $0.10,0.05$, and 0.10 levels, based on a one-sided alternative for signed predictions, and on a two-sided alternative otherwise. 
Table 6. Comparison of U.S. GAAP and IFRS firms' change in accounting quality from the period before the elimination of the reconciliation requirement to after

\begin{tabular}{|c|c|c|c|}
\hline $\begin{array}{l}\text { Earnings-Management } \\
\text { Metric }\end{array}$ & $\begin{array}{c}\text { POST - PRE } \\
\text { U.S. GAAP } \\
(\mathrm{N}=65)\end{array}$ & $\begin{array}{c}\text { POST }- \text { PRE } \\
\text { IFRS } \\
(\mathrm{N}=65)\end{array}$ & Difference \\
\hline Variability of $\Delta N I^{*}$ & 0.018 & 0.005 & $0.013^{* * *}$ \\
\hline Variability of $\triangle N I^{*}$ over $\triangle O C F^{*}$ & 1.500 & 0.625 & $0.875^{* * *}$ \\
\hline Correlation of $A C^{*}$ and $O C F^{*}$ & 0.002 & 0.007 & 0.005 \\
\hline Small Positive NI (POS) & 0.095 & 19.989 & -19.894 \\
\hline \multicolumn{4}{|l|}{ Timely Loss-Recognition } \\
\hline \multicolumn{4}{|l|}{ Metric } \\
\hline Large Negative $N I(N E G)$ & -1.010 & 0.527 & -1.537 \\
\hline Basu $R E T \times D U M$ Coefficient & 0.396 & 0.079 & $0.317^{*}$ \\
\hline Ball-Shivakumar $O C F \times I N D$ Coefficient & 0.621 & 0.440 & $0.181^{*}$ \\
\hline \multicolumn{4}{|l|}{ Value Relevance } \\
\hline \multicolumn{4}{|l|}{ Regression $R^{2}$} \\
\hline Price & 0.028 & 0.192 & $-0.164^{*}$ \\
\hline Good News & 0.107 & 0.361 & $-0.254^{* *}$ \\
\hline Bad News & 0.014 & 0.205 & $-0.191^{* *}$ \\
\hline
\end{tabular}

We base the analysis on regressions including controls defined in Table 2. We define the variability of $\triangle N I^{*}\left(\triangle O C F^{*}\right)$ as the variance of residuals from a regression of $\triangle N I(\triangle O C F)$ on the control variables, and the variability of $\triangle N I^{*}$ over $\triangle O C F^{*}$ as the ratio of the variability of $\triangle N I^{*}$ divided by the variability of $\triangle O C F^{*}$. Correlation of $A C^{*}$ and $O C F^{*}$ is the partial Spearman correlation between the residuals from a regression of $A C$ and $O C F$, respectively, on the control variables. $\triangle N I, \triangle O C F, A C$, and $O C F$ are defined in Table 2 .

For small positive (large negative) $N I$, we estimate a separate logit model for each measure by regressing an indicator variable (that equals 1 for foreign issuers adopting IFRS and 0 for those complying with U.S. GAAP reconciliations) on $P O S(N E G)$ and control variables. $P O S$ (NEG) equals 1 if annual net income deflated by total assets is between 0 and 0.01 (less than -0.20), and 0 otherwise; the coefficient on the indicator variable is reported.

The Basu RET $\times D U M$ coefficient is the estimate of $\pi_{3}$ and $\sigma_{3}$ for U.S. GAAP and IFRS observations, respectively, from the following regression: $E P S=U S G A A P \times\left[\pi_{0}+\pi_{1} R E T+\pi_{2} D U M+\pi_{3} R E T \times D U M\right]+I F R S \times\left[\sigma_{0}+\sigma_{1} R E T+\right.$ $\left.\sigma_{2} D U M+\sigma_{3} R E T \times D U M\right]+\varepsilon$, where $U S G A A P$ (IFRS) equals 1 for foreign issuers applying U.S. GAAP (IFRS), and 0 otherwise. $D U M$ is an indicator variable equal to 1 if the annual stock return is negative, and 0 otherwise. EPS and RET are defined in Table 2.

The Ball-Shivakumar $O C F \times I N D$ coefficient is the estimate of $\tau_{3}$ and $\xi_{3}$ for U.S. GAAP and IFRS observations, respectively, from the following regression: $A C=U S G A A P \times\left[\tau_{0}+\tau_{1} O C F+\tau_{2} I N D+\tau_{3} O C F \times I N D\right]+I F R S \times\left[\xi_{0}+\right.$ $\left.\xi_{I} O C F+\xi_{2} I N D+\xi_{3} O C F \times I N D\right]+\varepsilon$. IND equals 1 if cash flows from operations is negative, and 0 otherwise. $U S G A A P$ and IFRS are defined as above, and $A C$ and $O C F$ are defined in Table 2.

The price regression is based on a two-stage regression. In the first stage, $P$ is regressed on industry and country fixed-effect indicator variables, where $P$ is price as of six months after the fiscal year-end. The second-stage regression is $P^{*}=\theta_{0}+\theta_{1} B V P S+\theta_{2} N I P S+\varepsilon$, where $P^{*}$ is the residual from the first-stage regression. BVPS and NIPS are defined in Table 2. The good-/bad-news regression is based on a two-stage regression. In the first stage, EPS is regressed on industry and country fixed-effect indicator variables. The second stage regression is $E P S^{*}=\gamma_{0}+\gamma_{1} R E T$ $+\varepsilon$, where $E P S^{*}$ is the residual from the first-stage regression, and EPS and RET are defined in Table 2. Good-news (bad-news) observations are those for which $R E T$ is nonnegative (negative). $R^{2}$ is from the second-stage regressions.

${ }^{*},{ }^{* *}$, and ${ }^{* * *}$ indicate significant difference between the U.S. GAAP and IFRS firms at the $0.10,0.05$, and 0.10 levels, respectively (two-tailed). 
where $S E L E C T_{i t}$ is an indicator variable equal to 1 for foreign issuers voluntarily adopting IFRS, and 0 for foreign firms filing U.S. GAAP reconciliations. $R O A_{i t}$ is return on assets, which equals net income divided by total assets. $L E V_{i t}$ equals total liabilities divided by book value of equity. $S I Z E_{i t}$ equals the natural logarithm of the market value of equity. $C S_{i t}$ is an indicator variable equal to 1 if there is an increase in the par value of common stock during the year, and 0 otherwise. $D E B T_{i t}$ is an indicator variable equal to 1 if there is an increase in long-term debt during the year, and 0 otherwise. IND is indicator variables indicating a firm's industry membership based on the 2-digit SIC codes. For ease of presentation, industry dummy coefficients are suppressed.

Using the first-stage probit estimation, we then obtain $z_{i t}$, the fitted value of the probit regression index function, and calculate inverse Mills ratios $\left(M I L L_{i t}\right)$, i.e., $\varphi\left(z_{i t}\right) / \Phi\left(z_{i t}\right)$, where $\varphi$ is the standard normal density and $\Phi$ is the normal cumulative probability. In the second stage, we include $M I L L_{i t}$ in all the subsequent regression models as an additional control variable to correct for biased estimates that result from a nonrandom treatment effect.

In the second stage of the Heckman (1979) procedure, the (unreported) results show that the estimated coefficients for the inverse Mills ratio included in all our primary analyses are significant. However, all other coefficient estimates remain virtually unchanged and all prior inferences remain unchanged. That is, we obtain results similar to those reported in Tables 3 through 6 . Thus, the impact of self-selection on our results appears to be minimal.

\section{Conclusions}

This paper compares accounting-quality metrics for a broad sample of firms in 28 countries that cross-list on U.S. exchanges in the periods before and after the SEC permitted foreign issuers to use IFRS in financial reporting. Our investigation starts by comparing accounting-quality metrics for a sample of foreign issuers that apply IFRS to a matched sample of foreign firms that do not in the IFRS reporting period.

The results indicate that foreign issuers applying IFRS exhibit more earnings management and recognize losses in a less timely manner than do foreign firms filing U.S. GAAP reconciliations. However, the results also show that accounting data are more value relevant for IFRS firms than their counterparts. Differences in accounting quality between the two groups in the U.S. GAAP reconciliation period do not account for the IFRS reporting-period differences. We also compare accounting-quality metrics for IFRS firms before and after the SEC waived the reconciliation requirement and examine whether their changes in accounting quality are different from those of their counterparts. The results document that accounting quality deteriorates between the two periods for foreign firms adopting IFRS, because they are more likely to smooth earnings and less likely to recognize losses in a timely manner than foreign issuers filing U.S. GAAP reconciliations. Overall, the combined evidence suggests that for non-U.S. firms, applying IFRS does not enhance financial reporting when compared with firms filing U.S. GAAP reconciliations.

We acknowledge several limitations of this study. First, as with much of the international literature, our tests rely on small samples because of data limitations. Thus, a lack of power may drive some of our findings of no differences across the two accounting regimes. Second, we acknowledge that some of our sample firms voluntarily adopt IFRS, whereas the others mandatorily apply IFRS. Accordingly, our results may not fully reflect the effects of permitting IFRS in financial reporting. Third, this study documents whether adopting IFRS results in financial reporting that is comparable to U.S. GAAP reconciliations. One has to be cautious in comparing these findings to literature that compares accounting quality under IFRS to U.S. GAAP, however. Reconciling financial statements from local standards to U.S. GAAP is different from a comprehensive application of U.S. GAAP.

\section{Acknowledgements}

We thank the Editor-in-Chief and three anonymous referees for their many constructive and valuable comments and suggestions. We also appreciate funding from the National Science Council, Executive Yuan, Taiwan.

\section{References}

American Accounting Association's Financial Accounting Standards Committee. (2008a). A perspective on the SEC's proposal to accept financial statements prepared in accordance with International Financial Reporting Standards (IFRS) without reconciliation to U.S. GAAP. Accounting Horizons, 22(2), 241-248. http://dx.doi.org/10.2308/acch.2008.22.2.241

American Accounting Association's Financial Accounting and Reporting Section of the Financial Reporting Policy Committee (2008b). Response to the SEC release, "Acceptance from private foreign issuers of financial statement prepared in accordance with International Financial Reporting Standards without reconciliation to 
U.S. GAAP File No. S7-13-07”. Accounting Horizons, 22(2), 223-240. http://dx.doi.org/10.2308/acch.2008.22.2.223

Ball, R., Kothari, S.P., \& Robin, A. (2000). The effect of international institutional factors on properties of accounting earnings. Journal of Accounting and Economics, 29(1), 1-51. http://dx.doi.org/10.1016/S0165-4101(00)00012-4

Ball, R., Robin, A., \& Wu, J. S. (2003). Incentives versus standards: Properties of accounting income in four East Asian countries. Journal of Accounting and Economics, 36(1/3), 235-270. http://dx.doi.org/10.1016/j.jacceco.2003.10.003

Ball, R., \& Shivakumar, L. (2005). Earnings quality in UK private firms: Comparative loss recognition timeliness. Journal of Accounting and Economics, 39(1), 83-128. http://dx.doi.org/10.1016/j.jacceco.2004.04.001

Ball, R., \& Shivakumar, L. (2006). The role of accruals in asymmetrically timely gain and loss recognition. Journal of Accounting Research, 44(2), 207-242. http://dx.doi.org/10.1111/j.1475-679X.2006.00198.x

Barth, M.E., Landsman, W.R., \& Lang, M.H. (2008). International accounting standards and accounting quality. Journal of Accounting Research, 46(3), 467-498. http://dx.doi.org/10.1111/j.1475-679X.2008.00287.x

Barth, M.E., Landsman, W.R., Lang, M.H., \& Williams, C. (2012). Are IFRS-based and US GAAP-based Accounting Amounts Comparable? Journal of Accounting and Economics, 54(1), 68-93. http://dx.doi.org/10.1016/j.jacceco.2012.03.001

Bartov, E., Goldberg, S.R., \& Kim, M. (2005). Comparative value relevance among German, US, and international accounting standards: A German stock market perspective. Journal of Accounting, Auditing and Finance, 20(2), 95-119. http://dx.doi.org/10.1177/0148558X0502000201

Basu, S. (1997). The conservatism principle and the asymmetric timeliness of earnings. Journal of Accounting and Economics, 24(1), 3-37. http://dx.doi.org/10.1016/S0165-4101(97)00014-1

Bradshaw, M.T., \& Miller, G.S. (2008). Will harmonizing accounting standards really harmonize accounting? Evidence from non-U.S. firms adopting U.S. GAAP. Journal of Accounting, Auditing and Finance, 23(2), 233-263. http://dx.doi.org/10.1177/0148558X0802300206

CFA Institute. (2007). Comment letter to SEC dated October 2, 2007. Re: File No. S7-13-07. Retrieved from http://sec.gov/comments/s7-13-07/s71307-125.pdf

Chen, L, \& Sami, H. (2008). Trading volume reaction to the earnings reconciliation from IAS to U.S. GAAP. Contemporary Accounting Research, 25(1), 15-53. http://dx.doi.org/10.1506/car.25.1.1

Efron, B., \& Tibshirani, R. (1993). An introduction to the bootstrap. Chapman \& Hall, New York, NY.

Fitch Ratings. (2007). Comment letter to SEC dated September 25, 2007. Re: File No. S7-13-07. [Online] Available: http://sec.gov/comments/s7-13-07/s71307-101.pdf

Han, F., \& He, H. (2013). Cost of equity capital of foreign firms: Did bonding benefits diminish after the SEC's waiver of IFRS to U.S. GAAP reconciliation? Review of Accounting and Finance, 12(3), 1-31.

Hansen, B., Pownall, G., Prakash, R., \& Vulcheva M. (2012). Relaxing the reconciliation requirement in non-U.S. firms' SEC filings: Firm incentives, and changes in earnings informativeness. Working Paper, Virginia Tech University.

Harris, M.S., \& Muller III, K.A. (1999). The market valuation of IAS versus US-GAAP accounting measures using Form 20-F reconciliations. Journal of Accounting and Economics, 26(1/3), 285-312. http://dx.doi.org/10.1016/S0165-4101(99)00003-8

Heckman, J.J. (1979). Sample selection bias as a specification error. Econometrica, 47(1), 153-161. http://dx.doi.org/10.2307/1912352

Hung, M., \& Subramanyam, K.R. (2007). Financial statement effects of adopting International Accounting Standards: The case of Germany. Review of Accounting Studies, 12(4), 623-57. http://dx.doi.org http://dx.doi.org /10.1007/s11142-007-9049-9

Jiang, J., Petroni, K.R., \& Wang, I.Y. (2010). Did eliminating the 20-F reconciliation between IFRS and US GAAP matter? Working Paper, Michigan State University. 
Kim, Y., Li, H., \& Li, S. (2012). Does eliminating the Form 20-F reconciliation from IFRS to U.S. GAAP have capital market consequences? Journal of Accounting and Economics, 53(1/2), 249-250. http://dx.doi.org/10.1016/j.jacceco.2011.05.001

Lang, M., Raedy, J.S., \& Wilson, W. (2006). Earnings management and cross listing: Are reconciled earnings comparable to U.S. earnings? Journal of Accounting and Economics, 42(1/2), 255-283. http://dx.doi.org/10.1016/j.jacceco.2006.04.005

Lang, M., Raedy, J.S., \& Yetman, M.H. (2003). How representative are cross-listed firms? An analysis of firm and accounting quality. Journal of Accounting Research, 41(2), 363-396. http://dx.doi.org/10.1111/1475-679X.00108

Leuz C. (2003). IAS versus U.S. GAAP: Information asymmetry-based evidence from Germany's new market. Journal of Accounting Research, 41(3), 445-472. http://dx.doi.org/10.1111/1475-679X.00112

Leuz, C., Nanda, D., \& Wysocki, P.D. (2003). Earnings management and investor protection: An international comparison. Journal of Financial Economics, 69(3), 505-527. http://dx.doi.org/10.1016/S0304-405X(03)00121-1

Myers, J.N., Myers, L.A., \& Skinner, D.J. (2007). Earnings momentum and earnings management. Journal of Accounting, Auditing, and Finance, 22(2), 249-84. http://dx.doi.org/10.1177/0148558X0702200211

Reitenga, A., Buchheit, S., Yin, Q.J., \& Baker, T. (2002). CEO bonus pay, tax policy, and earnings management. The Journal of the American Taxation Association, 24(Supplement), 1-23. http://dx.doi.org/10.2308/jata.2002.24.s-1.1

Securities and Exchange Commission. (2007). Acceptance from private foreign issuers of financial statement prepared in accordance with International Financial Reporting Standards without reconciliation to U.S. GAAP. [Online] Available: http://www.sec.gov/rules/final/2007/33-8879.pdf.

Siconolfi, M. \& Salwen, K.G. (1992). Big board, SEC fight over foreign stocks. The Wall Street Journal, May 13, 1992.

Van Tendeloo, B., \& Vanstraelen, A. (2005). Earnings management under German GAAP versus IFRS. European Accounting Review, 14(1), 155-80. http://dx.doi.org/10.1080/0963818042000338988

Zeff, S.A. (2012). The evolution of the IASC into the IASB, and the challenges it faces. The Accounting Review, 87(3), 807-837. http://dx.doi.org/10.2308/accr-10246

\section{Notes}

Note 1. IFRS, overwhelmingly perceived as more "principles-based" rather than "rules-based," is a body of accounting standards issued by the IASB. Today more than 160 countries either mandate or permit the use of IFRS by public companies or are in the process of adopting these standards.

Note 2. Accounting literature documents significant differences between German GAAP and U. S. GAAP. These differences were highlighted in Daimler-Bernz's reconciliation financial statements. The company's reconciliation for 1993 showed a consolidated profit of DM0.6 billion under German GAAP but a loss of DM1.8 billion under U.S. GAAP, because the company had released "silent reserves" that had the effect of boosting its earnings. Accordingly, German and other Europe Union (EU) companies were urged to abandon their domestic GAAP and instead adopt U.S. GAAP or IFRS (Zeff, 2012). 